\title{
Medievalista
}

\section{Editorial. Manter o rumo, prosseguir com a Medievalista}

\section{(2) OpenEdition}

Journals

\section{Edição electrónica}

URL: http://journals.openedition.org/medievalista/259

DOI: 10.4000/medievalista.259

ISSN: 1646-740X

Editora

Instituto de Estudos Medievais - FCSH-UNL

\section{Refêrencia eletrónica}

"Editorial. Manter o rumo, prosseguir com a Medievalista », Medievalista [Online], 15 | 2014, posto online no dia 01 janeiro 2014, consultado o 22 setembro 2020. URL : http://journals.openedition.org/ medievalista/259; DOI : https://doi.org/10.4000/medievalista.259

\section{(c) $(1)(9$}

Mediavalista está licenciado com uma Licença Creative Commons - Atribuição-NãoComercial 4.0 Internacional. 
Título: Editorial. Manter o rumo, prosseguir com a Medievalista.

Fonte: Medievalista [Em linha]. №15, (Janeiro - Junho 2014). Dir. José Mattoso. Lisboa: IEM.

Disponível em: http://www2.fcsh.unl.pt/iem/medievalista/

ISSN: 1646-740X

\section{Editorial}

\section{Manter o rumo, prosseguir com a Medievalista}

\section{A Equipa de Redacção}

O presente número da Medievalista inaugura uma nova fase na vida da revista. Depois de um longo período de preparação, preenchendo requisitos científicos e resolvendo exigências técnicas e administrativas com custos financeiros, a nossa revista passa a integrar as plataformas LusOpen, DOAJ e SciELO. É mais um pequeno passo no caminho que a Medievalista vem percorrendo, mas que queremos que seja um grande passo na difusão e divulgação dos estudos medievais, por parte de uma publicação periódica, de carácter científico, elaborada e produzida em Portugal. 
Este é, por certo, um motivo de regozijo para todos os que entre nós se dedicam ao estudo da época medieval, sobretudo para aqueles que mais directamente se têm identificado com os objectivos e com a acção da Medievalista, lendo-a, acompanhandoa no seu trajecto, colaborando com ela de diversas formas. Entre esses e essas, evocamos neste número a obra e a personalidade de Teresa Amado, desaparecida do nosso convívio no passado mês de Agosto, e de quem José Mattoso escreve um justo e sentido In Memoriam. Na secção dos Artigos, incluem-se quatro estudos: de Mariel Pérez, sobre a aristocracia da Alta Idade Média, com destaque para as actuais tendências de investigação; de Marisa das Neves Henriques, sobre os físicos e a "medicina da alma" na obra O Orto do Esposo; de David Martín Lopéz, sobre a revalorização da época medieval na estética maçónica inglesa e escocesa dos séculos XIX e XX; e de Maria Coutinho, sobre a relação entre o texto e a iluminura no De Computo de Rábano Mauro.

$\mathrm{Na}$ secção de Recensões são apresentados dois livros recentes, sobre o claustro do mosteiro da batalha e sobre o processo dos Templários, dando conta de linhas actuais de pesquisa da medievística internacional. Na Apresentação de Teses são divulgadas as recentes dissertações de doutoramento de dois membros do IEM, sobre os eremitas da Serra de Ossa, da autoria de João Luís Inglês Fontes, e sobre o território da arquidiocese de Braga, da autoria de André Evangelista Marques. Por último, dá-se notícia do III Colóquio "A Nova Lisboa Medieval”, organizado pelo IEM e que decorreu na Faculdade de Ciências Sociais e Humanas da UNL, entre 20 e 22 de Novembro de 2013.

Mantendo a sua linha editorial, o seu carácter pluridisciplinar, a sua abertura às diversas orientações historiográficas que se regem pelo rigor e pela qualidade, preenchendo critérios de exigência que se pretende que pautem a arbitragem científica, a Medievalista confronta-se com os fortes desafios suscitados pela sua inclusão em novas plataformas de publicações da área das ciências sociais. Às exigências de natureza científica temos procurado corresponder com o aumento da qualidade e da diversidade dos artigos publicados, bem como com a crescente internacionalização da revista. Pelo que depende de nós, não deixaremos de procurar responder à devida altura. 
Mas quando está em curso um moroso, administrativamente pesado e por vezes ziguezagueante processo de avaliação das Unidades de Investigação financiadas pela Fundação para a Ciência e a Tecnologia, o nosso voto no início deste ano de 2014 vai para que o financiamento do único Centro português especificamente dedicado aos estudos medievais possa fazer face aos custos que acarretam as suas múltiplas actividades científicas - e, nomeadamente, a produção da Medievalista. Oxalá, também aqui, a resposta de quem a deve dar esteja à altura devida.

\section{COMO CITAR ESTE ARTIGO}

\section{Referência electrónica:}

"Editorial. Manter o rumo, prosseguir com a Medievalista". Medievalista [Em linha]. No15, (Janeiro - Junho 2014). [Consultado dd.mm.aaaa]. Disponível em http://www2.fcsh.unl.pt/iem/medievalista/MEDIEVALISTA15/editorial1501.html.

ISSN 1646-740X.

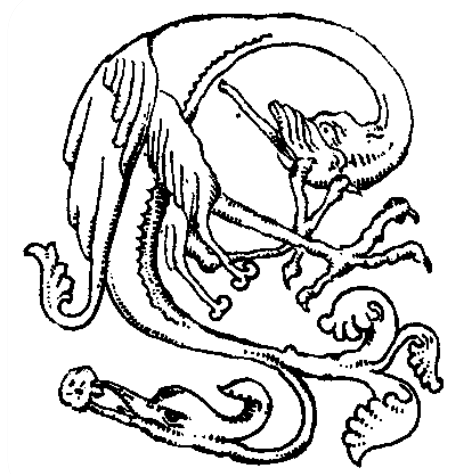

